\title{
Reactivity of the immunological system of rats stimulated with Biolex-Beta HP after cyclophosphamide immunosuppression
}

\author{
ROMAN WÓJCIK
}

Department of Microbiology and Clinical Immunology, Faculty of Veterinary Medicine, University of Warmia and Mazury in Olsztyn, Olsztyn, Poland

\begin{abstract}
The objective of this study was to determine the stimulating effect of the Biolex-Beta HP $(\beta-1,3 / 1,6$ D-glucan) dietary supplement on selected parameters of specific and non-specific humoral and cellular immunity in rats immunosuppressed with cyclophosphamide. The experimental material comprised 40 Wistar rats, divided into two equal groups: control and experimental. In the course of 3 successive days, the rats from the experimental group were administered cyclophosphamide intramuscularly at a rate of $50 \mathrm{mg} / \mathrm{kg} \mathrm{BW}$ per day. On the $8^{\text {th }}$ day of the experiment, 10 control and 10 experimental rats were sacrificed, and total protein and $\gamma$-globulin levels, lysozyme and ceruloplasmin activity were determined in the blood serum. The proliferative response of blood lymphocytes after stimulation with lipopolysaccharide or concanavalin A, respiratory burst activity and the potential killing activity of phagocytes were determined in whole heparinised blood. Starting on the $8^{\text {th }}$ day of the experiment, the feed of the remaining rats from the experimental and control groups was supplemented for 14 consecutive days with Biolex-Beta HP at a rate of $50 \mathrm{mg} / \mathrm{kg} \mathrm{BW}$ per day. On day 22, arterial blood samples were collected and immune parameters were determined. The results indicate that $\beta-1,3 / 1,6-D$-glucan has a positive effect on the analysed parameters of non-specific cellular and humoral immunity after cyclophosphamide-induced suppression. Nevertheless, the observed effect only marked a return to the norm, as most of the analysed parameters were merely restored to their initial levels, with the exception of lysozyme activity, which considerably exceeded the level noted before immunosuppression.
\end{abstract}

Key words: Biolex-Beta HP, immunosuppression, total protein levels, humoral and cellular immunity parameters.

(Centr Eur J Immunol 2014; 39 (1): 51-60)

\section{Introduction}

Immunosuppression, a dysfunction of the immune system, is triggered by a variety of biological (viruses, bacteria, fungi, parasites), chemical (water and feed contamination, antibiotics, heavy metals, disinfectants) and physical factors (stress, suboptimal temperature, excessive concentrations of dust and harmful gases). Prolonged exposure to those adverse factors can lead to the deterioration of health, lower body weight gains, lower effectiveness of preventive vaccination, higher susceptibility to cancer, infectious and parasitic diseases, induction of latent infections [1-5] and increased mortality that contributes to economic losses. To effectively counteract those adverse effects, scientists are searching for substances that augment the body's immune response. Those substances are known as immunostimulants or immunostimulators. Immunostimulants can accelerate, enhance or prolong the immune response subject to the immune status of the host, the route of administration and the applied dose [610]. Recent years have witnessed the growing popularity of immunostimulants, in particular substances of natural origin [11-15]. This group of natural stimulants includes $\beta-1,3 / 1,6-\mathrm{D}$-glucan (Biolex Beta-HP), which is analysed in the presented experiment. The branched $\beta-1,3 / 1,6$-glucan polysaccharide found in the Biolex-Beta HP product has the structure of a $\beta-1,3$ main chain connected to a $\beta-1,6$ side chain. This polysaccharide can be isolated from mannoproteins without the use of aggressive alkalis or acids in the hydrolysis process, and it occurs in an unmodified, natural form that guarantees the highest level of biological activity [16]. Due to their varied and complex structure, $\beta$-glucans can bind to various receptors ( $\beta$-glucan receptors) located on the surface of effector cells (macrophages, monocytes, neutrophils, NK cells, dendritic cells, T cells

Correspondence: Roman Wójcik, Department of Microbiology and Clinical Immunology, Faculty of Veterinary Medicine,

University of Warmia and Mazury in Olsztyn, Oczapowskiego 13, 10-957 Olsztyn, Poland; phone: +48 8952332 17; 5233454 ;

tel./fax +48 8952341 15; e-mail: brandy@uwm.edu.pl 
and B cells). They include dectin-1 [17, 18], complement receptor 3 (CR3, CD11b/CD18, $\alpha \mathrm{M} \beta 2$-integrin, Mac-1) $[19,20]$, lactosylceramide (LacCer) [21] and selected scavenger receptors (SRs) [22], including SR CD36 [23], TLR-2 (toll like receptor-2) and, probably, TLR-4 [24, $25]$. The binding process activates effector cells (NF- $\kappa \mathrm{B}$ - nuclear factor kappa-light-chain-enhancer of activated $B$ cells) and increases the secretion of proinflammatory chemokines and cytokines: TNF- $\alpha$ (tumour necrosis factor $\alpha$ ), interleukin-1 $\beta$ (IL-1 $\beta$ ), IL-6, IL-8, IL-12, interferon (IFN) $\gamma$ and IFN- $\beta 2[26,27]$. According to Pelizon et al. [28], IL-12, which stimulates the cellular immune response, plays a vital role in this process by enhancing lymphocyte proliferation, differentiating the subpopulations of Th1 lymphocytes from Th0 lymphocytes, and activating NK cells [29] that produce IFN- $\gamma$. Interferon $\gamma$ increases the phagocytic activity of macrophages (activated macrophages) and it strongly differentiates $\mathrm{Th}_{1}$ cells.

In the experiment, immunosuppression was not induced by an infection, which produces unpredictable results, but by a chemical substance that minimises the relevant risk. The researchers opted for cyclophosphamide due to its ability to deliver reliable and repeatable results within a short period of time. Cyclophosphamide is a cytotoxic alkylating agent that cross-links DNA and prevents its separation, which results in altered protein production, decreased cell division and cell death. Rapidly proliferating cells are most susceptible to cyclophosphamide's alkylating effects, and this observation has been used in cancer research. Cyclophosphamide also influences the cells of healthy tissues, including immune cells, bone marrow cells (in particular developing blood cells), activated lymphocytes (that proliferate and produce antibodies), foetal cells, hair follicle cells and intestinal epithelial cells [30]. Cyclophosphamide weakens both the cellular and humoral immune response. Its effect is dose-dependent, but even a single administration may temporarily impair the immune system [31]. Cyclophosphamide is widely used in the treatment of neoplastic and severe autoimmune diseases.

This study makes the first ever attempt to evaluate the effect of $\beta$-1,3/1,6-D-glucan isolated from Saccharomyces cerevisiae on rats immunosuppressed with cyclophosphamide. The aim of this study was to demonstrate the effect of Biolex-Beta HP on selected parameters of humoral and cellular immunity in cyclophosphamide-immunosuppressed rats.

\section{Material and methods}

Animals. Animal experiments were carried out in conformance with the Animal Protection Law (Journal of Laws of 24 February 2005, no. 33, item 289) and the recommendations of the Animal Ethics Committee of the University of Warmia and Mazury in Olsztyn. During the experiment, animals were kept in Faculty premises and adequate experimental conditions were observed.

Experimental design. The experimental material comprised 40 adult Wistar rats aged 14 weeks, including 20 females with average body weight $200 \mathrm{~g}$, and 20 males with average body weight $340 \mathrm{~g}$. The animals were initially divided into two groups (control and experimental) of 10 males and 10 females each. The males and females from each group were kept in separate cages. All animals were fed Murigran pelleted feed for rodents (Akropol Motycz) and had ad libitum access to water. Over a period of 3 consecutive days (days 1-3), 20 experimental group rats were administered cyclophosphamide ( $N, N$-bis (2-chloroethyl)-1,3,2-oxazaphosphinan-2-amine 2-oxide CAS 50-18-0, SIGMA) intramuscularly at the daily rate of $50 \mathrm{mg} / \mathrm{kg} \mathrm{BW}$ in the form of $75 \mathrm{~g} / \mathrm{l}$ PBS solution (phosphate buffered saline with the addition of calcium chloride and magnesium chloride, Biomed). On the $8^{\text {th }}$ day of the experiment, 10 control group rats $(\mathrm{K})$ and 10 experimental group rats (C) were sacrificed by an overdose of Narcotan (Halothanum, CAS 151-67-7, ZENTIVA, lot 3081006). Samples of arterial blood were collected to determine and compare selected biochemical parameters and parameters of non-specific humoral immunity in rats (total protein levels, $\gamma$ globulin levels, lysozyme activity, ceruloplasmin activity). Blood was diluted with heparin (Heparinum natricum, CAS 9005-49-6 Polfa Warsaw) to determine and compare selected parameters of non-specific cellular immunity in rats [proliferative response of blood lymphocytes (MTT) after stimulation with LPS or ConA, respiratory burst activity (RBA) and potential killing activity (PKA) of phagocytes]. Starting on the $8^{\text {th }}$ day of the experiment, the feed of the remaining 10 rats from the experimental group $(\mathrm{C}+\mathrm{G})$ and 10 rats from the control group $(\mathrm{G})$ was supplemented with $\beta$-1,3/1,6-D-glucan (Biolex-Beta HP, Leiber $\mathrm{GmbH}$ ) at the daily rate of $50 \mathrm{mg}$ / $\mathrm{kg} \mathrm{BW}$ for 14 consecutive days (days 8-21). On day 22, all $\mathrm{C}+\mathrm{G}$ and $\mathrm{C}$ group rats were sacrificed by an overdose of Narcotan, and samples of arterial blood were collected to determine and compare selected biochemical parameters and parameters of non-specific humoral immunity in rats. Blood was diluted with heparin to determine and compare selected parameters of non-specific cellular immunity in rats. A group treated with cyclophosphamide and tested after 22 days was not established because in our previous study [32] cyclophosphamide also exerted a suppressive effect on the analysed parameters between day 8 and day 22 of the experiment, in comparison with the control group (not treated with cyclophosphamide), and only minor variations in those parameters were noted after day 22.

Evaluation of non-specific humoral immunity parameters. Lysozyme activity in blood plasma was determined by the turbidimetric method [33] modified by Siwicki and Anderson [34], ceruloplasmin activity in blood plasma was evaluated by the method developed by Siwicki 
and Studnicka [35], $\gamma$-globulin levels in blood serum were determined by the precipitation method modified by $\mathrm{Si}$ wicki and Anderson [34], and total protein levels in blood serum were determined by spectrophotometry according to the method described by Lowry et al. [36] and modified by Siwicki and Anderson [34].

Lysozyme activity. Whole blood samples were centrifuged for $5 \mathrm{~min}$ at $1,000 \mathrm{~g}$ to separate blood cells from the serum. The serum was diluted $1: 1$ with phosphate buffer, and $0.1 \mathrm{ml}$ of the solution was placed in microplate wells. $0.5 \mathrm{ml}$ of Micrococcus lysodeikticus bacterial suspension (25 mg bacteria/100 ml phosphate buffer) (Sigma Chemical Co.) was added. Absorbance was measured directly after the addition of bacteria $\left(\mathrm{E}_{0}\right)$ and after 1, 2, 3 and 30 minutes (final E). The final absorbance was subtracted from the initial absorbance $\left(\mathrm{E}_{0}\right)$ to determine lysozyme activity with the use of a standard curve. The standard curve was plotted based on the optical density values for known lysozyme concentrations.

Ceruloplasmin activity. Whole blood samples were centrifuged for $5 \mathrm{~min}$ at $1,000 \mathrm{~g}$ to separate blood cells from the serum. The following buffers were prepared: 1) acetate buffer ( $\mathrm{pH} 5.2$, containing crystalline acetic acid, sodium acetate trihydrate and $15 \mathrm{mg}$ EDTA), 2) buffered substrate solution $(0.2 \%$ p-phenyldiamine (PPD) in acetic buffer), and 3 ) sodium azide solution $(0.02 \%$ sodium azide solution in deionised water). $0.5 \mathrm{ml}$ of buffered solution was added to each of the two $16 \times 100 \mathrm{~mm}$ test tubes immersed in a water bath at a temperature of $37^{\circ} \mathrm{C}$. One test tube served as the experimental sample, and the other one was the control. $50 \mu \mathrm{l}$ of the serum was added to the experimental sample which was incubated for $15 \mathrm{~min}$ at $37^{\circ} \mathrm{C}$. $2 \mathrm{ml}$ of sodium azide solution was added to experimental and control samples. $50 \mu \mathrm{l}$ of the serum was added to the control sample, and both samples were mixed. The absorbance of the experimental sample was measured at the wavelength of $540 \mathrm{~nm}$, and the control served as a blind sample. Ceruloplasmin activity was determined with the use of a standard curve. The standard curve was plotted based on the optical density values for known ceruloplasmin concentrations.

Gammaglobulin levels. Whole blood samples were centrifuged for $5 \mathrm{~min}$ at $1,000 \mathrm{~g}$ to separate blood cells from the serum. The optical density of total protein was determined in the blood serum. $0.1 \mathrm{ml}$ of the serum was placed in microplate wells, and $0.1 \mathrm{ml}$ of $12 \%$ polyethylene glycol (10,000 kD) (Sigma Chemical Co.) suspended in deionised water was added. The microplates were incubated at room temperature for $2 \mathrm{~h}$, and well contents were stirred continuously. The microplates were centrifuged for $10 \mathrm{~min}$ at 5,000 $\mathrm{g}$ to separate the $\gamma$-globulin fraction bound by polyethylene glycol (plate sediment) from the remaining total protein fraction that constituted the supernatant. The optical density of the supernatant was measured in a microplate reader at $620 \mathrm{~nm}$. The optical density of the supernatant was subtracted from the optical density of total protein. $\gamma$-globulin levels were determined using a standard curve (plotted earlier for total protein) as the reference based on the ability of gamma globulins to bind with polyethylene glycol and precipitate.

Total protein levels. Whole blood samples were centrifuged for $5 \mathrm{~min}$ at 1,000 $\mathrm{g}$ to separate blood cells from the serum. $5 \mu \mathrm{l}$ of the serum was placed in microplate wells, and $25 \mu \mathrm{l}$ of reagent A and $200 \mu$ of reagent B were added (Rio-Rad, Hercules, CA). The well contents were gently stirred with a pipette. The microplates were incubated at room temperature for $15 \mathrm{~min}$. The optical density was measured in a microplate reader at $620 \mathrm{~nm}$. Total protein levels were determined using a standard curve as the reference. The standard curve was plotted based on optical density values for known protein dilutions.

Evaluation of non-specific cellular immunity parameters. The metabolic activity of phagocytes was determined based on intracellular measurements:

Respiratory burst activity (RBA) was measured after stimulation with PMA (Phorobol Myristate Acetate, Sigma) as described by Chung and Secombes [37] and modified by Siwicki et al. [38]. The isolated cells were resuspended in RPMI-1640 medium (Sigma) at $10^{6}$ cells/ $\mathrm{ml}$. In 96-well U-shaped microplates, $100 \mu \mathrm{l}$ of isolated blood leukocytes was mixed with $100 \mu$ of $0.2 \%$ nitro blue tetrazolium (NBT, Sigma) solution in $0.2 \mathrm{M}$ phosphate buffer at $\mathrm{pH} 7.2$, and $1 \mu \mathrm{l}$ of PMA with a concentration of $1 \mathrm{mg} / \mathrm{ml}$ in ethanol was added. After $30 \mathrm{~min}$ of incubation at $37^{\circ} \mathrm{C}$, the supernatant was removed from each well. The cell pellet was washed with absolute ethanol and, three times, with $70 \%$ ethanol, then it was dried at room temperature. The amount of extracted reduced NBT after incubation with $2 \mathrm{M} \mathrm{KOH}$ and DMSO (dimethylsulfoxide, Sigma) was measured colourimetrically at $620 \mathrm{~nm}$ in a microplate reader (Tecan Sunrise). All samples were tested in triplicate, and the results are presented as mean values.

The potential killing activity (PKA) of mononuclear phagocytes and polymorphonuclear phagocytes was determined in isolated blood leukocytes stimulated with killed microorganisms, according to the method presented by Rook et al. [39] and adapted by Siwicki et al. (2004). In 96-well U-shaped microplates, $100 \mu 1$ of leukocytes was mixed with $100 \mu \mathrm{l}$ of $0.2 \%$ NBT in phosphate buffer at $\mathrm{pH}$ 7.2, and $10 \mu \mathrm{l}$ of killed Staphylococcus aureus strain 209P (containing $10^{6}$ bacteria) was added. The mixture was incubated for $1 \mathrm{~h}$ at $37^{\circ} \mathrm{C}$, and the supernatant was removed. The cell pellet was washed with absolute ethanol and, three times, with $70 \%$ ethanol, and it was dried at room temperature. $2 \mathrm{M} \mathrm{KOH}$ and DMSO were added to each well. The amount of extracted reduced NBT was measured at 620 $\mathrm{nm}$ in a microplate reader (Tecan Sunrise). All samples were tested in triplicate, and the results are presented as mean values. 
The proliferative response of blood lymphocytes. The proliferative response of blood lymphocytes after stimulation with mitogens, concanavalin A (ConA) and lipopolysaccharide (LPS) was determined by MTT spectrophotometry (OD $570 \mathrm{~nm}$ ) using (3-[4,5-dimethylthiazol-2-yl]-2,5-diphenyltetrazolium bromide), as described by Mosmann [40].

MTT (Sigma) was dissolved in PBS at the concentration of $5 \mathrm{mg} / \mathrm{ml}$ and filtered. In 96-well culture plates (Sarstetd, USA), $100 \mathrm{ml}$ of blood lymphocytes in RPMI 1640 containing $10 \%$ FCS, $2 \mathrm{mM}$ L-glutamine, $0.02 \mathrm{mM}$ 2-mercaptoethanol, 1\% HEPES buffer and penicillin/streptomycin $(100 \mathrm{U} / 100 \mathrm{mg} / \mathrm{ml})$ were mixed with $100 \mathrm{ml}$ of RPMI 1640 containing mitogens ConA $(5 \mathrm{mg} / \mathrm{ml})$ or LPS $(20 \mathrm{mg} / \mathrm{ml})$. After $72 \mathrm{~h}$ of incubation at $37^{\circ} \mathrm{C}$ in a $5 \%$ carbon dioxide atmosphere (Memmert Incubator), $50 \mathrm{ml}$ of MTT solution was added to each well, and plates were incubated for $4 \mathrm{~h}$ at $37^{\circ} \mathrm{C}$. After incubation, the plates were centrifuged $\left(1,400 \mathrm{~g}, 15^{\circ} \mathrm{C}, 5 \mathrm{~min}\right)$. Supernatants were removed, and $100 \mathrm{ml}$ of DMSO (Sigma) was added to each well and incubated for $15 \mathrm{~min}$ at room temperature. After incubation, the solubilised reduced MTT was measured

Table 1. The effect of Biolex-Beta HP on protein levels in cyclophosphamide-immunosuppressed rats

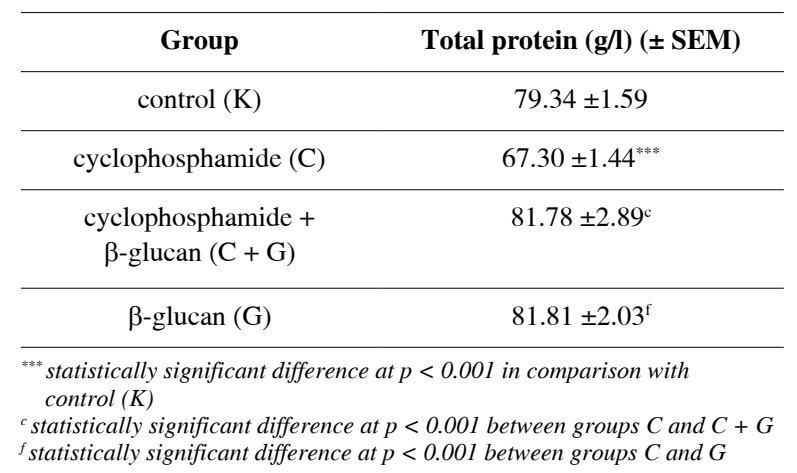

colourimetrically at $620 \mathrm{~nm}$ in a microplate reader (Tecan Sunrise). All samples were tested in triplicate, and the results are presented as mean values. The final results are presented as the reactivity index (RI).

\section{Statistical analysis}

The results were verified statistically by one-way ANOVA (GraphPadPrism software package), and the significance of differences between the groups was evaluated with the Bonferroni test.

\section{Results}

The administration of cyclophosphamide (C) to rats led to a statistically significant $(p \leq 0.01)$ decrease (by $15 \%)$ in total serum protein in comparison with the control group (K) (Table 1). After the administration of $\beta$-glucan, total protein levels in cyclophosphamide-immunosuppressed rats (group $\mathrm{C}+\mathrm{G}$ ) increased significantly (by 21\%) and reached a similar level to that noted in the control group $(\mathrm{K})$ and in the group administered only $\beta$-glucan $(\mathrm{G})$. No statistically significant differences were found between those three groups $(\mathrm{C}+\mathrm{G}, \mathrm{K}$ and $\mathrm{G})$.

Significantly $(P \leq 0.001)$ lower values of humoral immunity indicators in rats, i.e. lysozyme activity, ceruloplasmin activity and serum concentrations of gamma globulins (Table 2), were noted in the group of cyclophosphamide-immunosuppressed animals. The administration of cyclophosphamide to rats (C) decreased lysozyme activity (by 33\%), ceruloplasmin activity (by $21 \%$ ) and $\gamma$-globulin levels (by $19 \%$ ), in comparison with the control group. The stimulation of immunosuppressed rats $(\mathrm{C}+\mathrm{G})$ with $\beta$-glucan improved the values of the above parameters. A significant, more than two-fold increase in lysozyme activity was observed in comparison with cyclophosphamide-immunosuppressed rats (C), and lysozyme activity increased by more than $50 \%$ in comparison with the controls (K). Ceruloplasmin activity

Table 2. The effect of Biolex-Beta HP on non-specific humoral immunity parameters in cyclophosphamideimmunosuppressed rats

\begin{tabular}{|c|c|c|c|c|}
\hline \multirow[b]{2}{*}{ Parameter } & \multicolumn{4}{|c|}{ Group } \\
\hline & Control (K) & Cyclophosphamide (C) & $\begin{array}{c}\text { Cyclophosphamide }+ \\
\beta \text {-glucan }(C+G)\end{array}$ & $\beta$-glucan (G) \\
\hline $\begin{array}{l}\text { lysozyme activity } \\
(\mathrm{mg} / \mathrm{l})( \pm \mathrm{SEM})\end{array}$ & $9.06 \pm 0.56$ & $6.10 \pm 0.24^{* * *}$ & $12.90 \pm 1.07^{* * *, c}$ & $14.78 \pm 1.31^{* * *, \mathrm{f}, \mathrm{i}}$ \\
\hline $\begin{array}{l}\text { ceruloplasmin activity } \\
\qquad(\mathrm{mg} / \mathrm{l})( \pm \mathrm{SEM})\end{array}$ & $101.90 \pm 1.90$ & $80.30 \pm 2.66^{* * *}$ & $102.70 \pm 2.97^{c}$ & $105.23 \pm 3.54^{\mathrm{f}}$ \\
\hline $\begin{array}{c}\gamma \text {-globulin level } \\
(\mathrm{g} / \mathrm{l})( \pm \mathrm{SEM})\end{array}$ & $13.42 \pm 0.35$ & $10.88 \pm 0.39^{* * * *}$ & $13.20 \pm 0.98^{c}$ & $16.54 \pm 1.07^{* * *, \mathrm{f}, \mathrm{i}}$ \\
\hline
\end{tabular}

\footnotetext{
${ }^{* * *}$ statistically significant difference at $p<0.001$ in comparison with control $(K)$

${ }^{c}$ statistically significant difference at $p<0.001$ between groups $C$ and $C+G$

${ }^{{ }}$statistically significant difference at $p<0.001$ between groups $C$ and $G$

${ }^{i}$ statistically significant difference at $p<0.001$ between groups $C+G$ and $G$
} 
Table 3. The effect of Biolex-Beta HP on the parameters of specific and non-specific cellular immunity in cyclophosphamide-immunosuppressed rats

\begin{tabular}{|c|c|c|c|c|}
\hline \multirow[t]{2}{*}{ Parameter } & \multicolumn{4}{|c|}{ Group } \\
\hline & Control (K) & Cyclophosphamide (C) & $\begin{array}{c}\text { Cyclophosphamide }+ \\
\beta \text {-glucan }(\mathbf{C}+\mathbf{G})\end{array}$ & $\beta$-glucan (G) \\
\hline $\begin{array}{c}\text { RBA } \\
\text { (OD } 620 \mathrm{~nm})\end{array}$ & $0.42 \pm 0.03$ & $0.24 \pm 0.02^{* * *}$ & $0.51 \pm 0.08^{c}$ & $0.62 \pm 0.12^{* * *, \mathrm{f}, \mathrm{g}}$ \\
\hline $\begin{array}{c}\text { PKA } \\
\text { (OD } 620 \mathrm{~nm})\end{array}$ & $0.43 \pm 0.04$ & $0.29 \pm 0.01^{* * * *}$ & $0.49 \pm 0.07^{c}$ & $0.51 \pm 0.06^{* *, \mathrm{f}}$ \\
\hline $\begin{array}{l}\text { MTT-ConA } \\
\text { (RI) }\end{array}$ & $1.03 \pm 0.12$ & $0.54 \pm 0.17^{* * *}$ & $1.01 \pm 0.05^{\mathrm{c}}$ & $1.23 \pm 0.14^{* *, f, \mathrm{~h}}$ \\
\hline $\begin{array}{l}\text { MTT-LPS } \\
\text { (RI) }\end{array}$ & $1.04 \pm 0.04$ & $0.51 \pm 0.13^{* * *}$ & $1.09 \pm 0.11^{\mathrm{c}}$ & $1.19 \pm 0.19^{f}$ \\
\hline
\end{tabular}

\footnotetext{
${ }^{*}$ statistically significant difference at $p<0.01$ in comparison with control $(K)$

**** statistically significant difference at $p<0.001$ in comparison with control $(K)$ ${ }^{c}$ statistically significant difference at $p<0.001$ between groups $C$ and $C+G$

${ }^{f}$ statistically significant difference at $p<0.001$ between groups $C$ and $G$

${ }^{g}$ statistically significant difference at $p<0.05$ between groups $C+G$ and $G$

${ }^{h}$ statistically significant difference at $p<0.01$ between groups $C+G$ and $G$
}

and $\gamma$-globulin concentrations increased by $28 \%$ and $21 \%$, respectively, in comparison with group $\mathrm{C}$ and reached a similar level to that noted in the control group (K). Statistically significant differences between the group of rats fed $\beta$-glucan $(\mathrm{G})$ and the control group (K) were not reported only with regard to ceruloplasmin activity.

The indicators of non-specific cell-mediated immunity, i.e. respiratory burst activity (RBA) and potential killing activity (PKA) of phagocytes, and the parameters of specific cell-mediated immunity, i.e. proliferation rates of lymphocytes (MTT assay) stimulated with LPS and ConA (Table 3), were significantly $(P \leq 0.001)$ lower in the group of rats immunosuppressed with cyclophosphamide (C) in comparison with control (K). The respiratory burst activity (RBA) and potential killing activity (PKA) of phagocytes in immunosuppressed rats fed $\beta$-glucan $(\mathrm{C}+\mathrm{G})$ were significantly higher (by $113 \%$ and $69 \%$, respectively) than in the group of cyclophosphamide-immunosuppressed animals (C). The above parameters did not differ significantly from those noted in the control group. The respiratory burst activity (RBA) and the potential killing activity (PKA) of phagocytes in rats fed $\beta$-glucan $(\mathrm{G})$ were significantly higher (by $48 \%$ and $19 \%$, respectively) than in the control group (K). The proliferative capacity of T cells (ConA) and B cells (LPS) increased in immunosuppressed rats fed $\beta$-glucan $(\mathrm{C}+\mathrm{G})$ to the level noted in the control group. Statistically significant differences between the group of rats fed $\beta$-glucan $(\mathrm{G})$ and the control group $(\mathrm{K})$ were reported only with respect to the proliferative capacity of $\mathrm{T}$ cells (ConA).

\section{Discussion}

In the present study, cyclophosphamide inhibited protein production and decreased total protein and protein fractions. The administration of cyclophosphamide led to a decrease in $\gamma$-globulin levels and ceruloplasmin activity. The noted decrease could be attributed to cyclophosphamide's direct and/or indirect effect on hepatocytes that produce various protein fractions: albumins, $\alpha$-globulins (including ceruloplasmin) and C-reactive protein (CRP) $-\gamma$-globulin. Cyclophosphamide could exert a direct influence on hepatocytes by inhibiting the activity of liver enzymes responsible for protein synthesis. Its indirect effect, which is of particular importance for acute phase proteins, including ceruloplasmin, could result from impaired synthesis of proinflammatory cytokines (IL-1, IL-6 and TNF- $\alpha$ ), which are produced mainly by monocytes/ macrophages that stimulate the synthesis of acute phase proteins in the liver. The mechanism responsible for cyclophosphamide's hepatotoxicity has never been described in literature. The results reported by King and Perry [41] seem to confirm cyclophosphamide's inhibitory effect on selected liver enzymes. The cited authors suggested that cyclophosphamide does not exert direct hepatotoxic effects, but that its action is mediated by cytochrome P450, which converts the drug to active metabolites. In the above study, intensive changes that accompany the administration of large doses of cyclophosphamide led to disrupted hepatocyte function and synthesis of selected proteins. Cyclophosphamide's hepatotoxic effects and the resulting death of hepatocytes were also noted by Aubrey [42] in a breast cancer patient and by Snayder et al. [43] in a granuloma patient undergoing cyclophosphamide therapy. The observed drop in the concentrations of immunoglobulins, the $\gamma$-globulin fraction of total protein, can also be attributed to cyclophosphamide's direct effect on plasma cells, which involves the inhibition of protein synthesis, and its indirect effect on B cell proliferation. A drop in the number of proliferating cells could imply a decrease in plasma cell 
counts and the produced antibodies. The above hypothesis seems to be validated by the findings of Čejka et al. [44], who observed a decrease in immunoglobulin and $\beta_{2}$-microglobulin levels in a patient with acute leukaemia after cyclophosphamide treatment. Zhu et al. [45] noted a drop in the ability of B cells to differentiate into plasma cells and secrete immunoglobulins in patients subjected to long-term treatment with low doses of cyclophosphamide. The effect of cyclophosphamide on ceruloplasmin levels was investigated by Abreu and Abreu [46], who administered the drug to rats with syngeneic sarcomas. In the above study, the physiological levels of ceruloplasmin were restored already after just a single dose of cyclophosphamide (100 $\mathrm{mg} / \mathrm{kg} \mathrm{BW}$ ).

In the present experiment, total protein and ceruloplasmin activity were restored to their initial levels after the administration of $\beta$-glucan to cyclophosphamide-immunosuppressed rats, whereas gamma globulin levels were higher than before immunosuppression. $\beta$-glucans had a stimulating effect on $\gamma$-globulin and ceruloplasmin levels in our earlier studies of non-immunosuppressed rats administered Biolex Beta-HP [47], non-immunosuppressed lambs fed Biolex MB-40 [48], and 28-, 50- and 70-day-old lambs whose mothers had been administered Saccharomyces cerevisiae dry brewer's yeast (Inter Yeast) from the fourth month of pregnancy or after lambing [13]. The above effect can be attributed to $\beta$-glucan binding to $\beta$-glucan receptors on macrophages and/or granulocytes, which activates the nuclear transcription factor (NF- $\kappa \mathrm{B})$ for genes encoding inflammatory proteins, such as cytokines and chemokines, and induces free radical production [49]. Estrada et al. [50] demonstrated in vitro an increase in IL- $1 \alpha$ production by murine macrophages in the presence of oat $\beta$-glucans and enhanced secretion of interleukin (IL)-2, IFN- $\gamma$ and IL-4 by spleen cells. Interleukin 4 stimulates Th2 cell development to produce IL-5, IL-6, IL-10 and IL-13, which are involved in the humoral immune response, and it stimulates the production of antibodies. In a study by Suzuki et al. [51], isolated splenocytes from mice administered SSG increased IgG2a production and decreased $\mathrm{IgG} 1$ production. Since IgG2a responses are induced by IFN- $\gamma$ and suppressed by IL-4, whereas immunoglobulin (Ig) G1 production is inhibited by IFN- $\gamma$ and stimulated by IL-4, those responses were identified as Th1 and Th2 antibody responses, respectively. Estrada et al. [52] reported on the stimulating effects of oat $\beta$-glucans in dexamethasone-immunosuppressed beef steers, which led to an increase in serum levels of specific (after simulation with leech ovalbumin and hemocyanin) and non-specific IgG. It should be noted, however, that gamma globulin levels account not only for specific antibodies, but also for haemagglutinin and haemolysin - antibodies of the first class that play a very important role in non-specific humoral immune response. $\beta$-glucans can also stimulate phagocytes to produce IL-1, IL-6 and TNF- $\alpha$, which stim- ulate the synthesis of acute phase proteins in hepatocytes. The above processes could be responsible for the observed increase in ceruloplasmin activity [53]. Guzdek and Rokita [54] demonstrated the stimulating effects of curdlan sulphate (a sulphate derivative of curdlan $-1,3-\beta$-glucan) on the levels of selected blood proteins, including ceruloplas$\min$. The noted increase is of significance because ceruloplasmin, an acute phase protein that is implicated in the non-specific humoral immune response, contributes to the quick restoration of homeostasis.

In the present study, cyclophosphamide contributed to a decrease in the activity of lysozyme (which is also a $\gamma$-globulin) produced by phagocytes. Zhao et al. [55] administered this drug to rats and reported a decrease in serum lysozyme levels, the percentage phagocytosis and the macrophage phagocytic index. According to Yang [56], the above could be attributed to a drop in the number of phagocytes, impairment of phagocytosis and the release of lysozyme into the plasma by macrophages [57-59]. However, after the administration of $\beta$-glucan to immunosuppressed rats, lysozyme activity increased and considerably exceeded the levels noted in the control group. A similar increase in lysozyme activity was noted by Ząbek et al. [60] in the blood serum of non-immunosuppressed sheep fed Biolex ${ }^{\circledR}$-Beta $S(\beta-1,3 / 1,6-D$-glucan). Paulsen et al. [61] have suggested that $\beta$-glucan directly activates the transcription of lysozyme genes (much higher expression of lysozyme mRNA was noted in macrophages stimulated with $\beta$-glucan). According to Kokoshis et al. [62], the increase in lysozyme activity after stimulation with $\beta$-glucan is proportional to the phagocytic efficiency of macrophages, which is also determined by $\beta$-glucan stimulation. Activated macrophages containing more lysosomes and lysosomal enzymes expresses more histocompatibility complex class II proteins [63]. A study of mice [64] also demonstrated that serum levels of lysozyme do not always increase in response to the administration of $\beta$-glucans.

The results of our experiment indicate that cyclophosphamide had a negative effect on the respiratory burst activity (RBA) and the potential killing activity (PKA) of phagocytes. The values of the investigated parameters decreased in immunosuppressed rats. The negative effect cyclophosphamide could result from its indirect or direct influence on phagocytes. The analysed drug exerts a direct effect by alkylating DNA, RNA and enzymes, which impairs phagocytic function at different stages of phagocytosis. The above can inhibit chemotaxis, synthesis of cytokines, enzymes, substances present in macrophage lysozymes and granulocyte granules, receptors for complement protein C3 (CR3), Fc antibody fragments (FcR) or toll-like receptors that directly bind microbial products (TLR). Cyclophosphamide exerts a similar effect by influencing the production of cytokines released by lymphocytes [65-71].

In this study, dietary supplementation with $\beta$-glucan enhanced the activity of monocytes and granulocytes in 
rats, leading to an increase in the respiratory burst activity (RBA) and the potential killing activity (PKA) of phagocytes. $\beta$-glucans stimulated phagocytic activity in our earlier studies of non-immunosuppressed lambs fed Biolex-Beta HP [12] and Biolex MB40 [48]. In a study by Lowry et al. [72], immature chickens fed purified $\beta$-glucan were more resistant to infections caused by Salmonella enteric, which was manifested by increased phagocytosis, bactericidal killing and oxidative burst of isolated heterophiles (neutrophil-like cells in chickens). $\beta$-glucans are activated when they are bound to TLR-2 (toll-like receptor 2), TLR-4, TLR-6, dectin-1, CR3 (complement receptor 3), lactosylceramide and scavenger receptors on the phagocytes [21, 22, 73-76]. According to Schepetkin and Quinn [53], the activation of $\beta$-glucans affects both extracellular (intensified chemokinesis, chemotaxis and degranulation, which lead to increased expression of adhesive molecules on phagocyte surface and adhesion to the endothelium) and intracellular processes (increased respiratory burst formation of reactive oxygen and nitrogen species, free radicals, higher levels and activity of hydrolytic and metabolic enzymes). $\beta$-glucans can stimulate the production and activity of cytokines, including tumour necrosis factor $\alpha$ (TNF- $\alpha)$, IL-1, IL-2, IL-6, IL-10 and IL-12, by activating nuclear factor $\kappa \mathrm{B}(\mathrm{NF}-\kappa \mathrm{B})[77,78]$. According to Chan et al. [79], $\beta$-glucans can also induce the proliferation of peripheral blood mononuclear cells. $\beta$-glucans enhance phenotypic and functional maturation of monocyte-derived dendritic cells and stimulate IL-12 production. An increase in IL-12 levels contributes to the differentiation of Th0 cells into Th1 cells, which leads to the production of typical Th1 cytokines, including IL- $1 \beta$, IFN- $\gamma$, IL-2 and TNF- $\alpha$, which play an important role in cell-mediated immunity [80-82]. Interferon $\gamma$ and IL-2 stimulate the production of activated macrophages characterised by their greater ability to engulf and destroy bacteria [83, 84]. Hamuro et al. [85] suggested another possible mechanism of phagocyte activation by $\beta$-glucans, whereby the elements of the complement, in particular $\mathrm{C} 3 \mathrm{~b}$, are activated.

In the present experiment, cyclophosphamide reduced the proliferative capacity of T cells and B cells in rats after mitogenic stimulation. Our findings suggest that both lymphocyte populations are sensitive to cyclophosphamide. The immunosuppressive effects of cyclophosphamide were also observed in vivo in mice and in vitro in human lymphocytes whose ability to proliferate was visibly reduced after stimulation with mitogens (LPS, ConA, phytohaemagglutinin - PHA or pokeweed mitogen - PWM) or the thymus-dependent antigen (sheep erythrocytes) [56, 58, 59, 86, 87]. According to Quakyi et al. [88], Bafna and Mishra [89], a single dose of cyclophosphamide inhibited the proliferative response to both $\mathrm{B}$ and $\mathrm{T}$ cells. The production of antibodies is gradually restored after 3-6 weeks, but the inhibition of mitogen-stimulated lymphocyte proliferation is sustained even after 5 weeks [90].
Cyclophosphamide's negative influence could result from its direct or indirect effect on cells. The analysed drug directly contributes to the formation of cross-links between nitrogen bases in DNA, which negatively affects daughter cells. Indirectly, cyclophosphamide exerts a negative effect on monocytes/macrophages that control lymphocyte function [91-95].

In this study, dietary supplementation with $\beta$-glucan stimulated the proliferative activity of T and B cells. $\beta$-glucan exerts a direct effect by binding with glucan receptors on the surface of B cells (human and mouse B cells express Dectin-1) and T cells ( $\alpha \beta$ T cell receptors $-\alpha \beta$ TCRs) to induce a cascade reaction and activate the NF- $\kappa \mathrm{B}$ transcription factor [96-100]. NF- $\kappa B$ induces the expression of cytokines, mostly IL-2 and IL-4, which stimulate the proliferation of B and T cells [101, 102]. $\beta$-glucan also exerts an indirect effect by activating phagocytes (macrophages and dendritic cells) that remain in a mutual relationship with lymphocytes and release various lymphocyte-stimulating cytokines (IL-2, IL-10, IL-12, TNF- $\alpha$ ) [77, 79, 103]. $\beta$-glucan's stimulating influence on the proliferative activity of lymphocytes was also noted by other authors. Zhao et al. [104] observed an increase in the activity of lymphocytes stimulated with LPS and ConA after the administration of a different glucan type, FPS-1 (1,6- $\beta$-glucan found in Aconitum carmichaelii). In an in vivo study of mice analysing the effectiveness of six polysaccharides [105], a similar increase in the proliferative activity of lymphocytes was induced by only three of the tested compounds: Astragalan (extract from Astraglus membranaceus), lentinan (extract from Lentinula edodes) and ganoderan (extract from Ganoderma lucidum).

Bi et al. [106] reported higher proliferation levels of B cells (stimulated with LPS) and T cells (stimulated with ConA) in mice orally administered three branched $(1 \rightarrow 6)-\beta$-D-glucans (BIK2, BIK10 or BIK30) and one unbranched $(1 \rightarrow 6)$ - $\beta$-D-glucan (BIWP2) for 10 days, in the amount of 10 and $50 \mathrm{mg} / \mathrm{kg} / \mathrm{day}$.

The reported results clearly indicate that $\beta-1,3 / 1,6-\mathrm{D}$ glucan has a positive effect on the analysed parameters of non-specific cellular and humoral immunity after immunosuppression with cyclophosphamide. Owing to its high efficacy, $\beta$-1,3/1,6-D-glucan contributed to an improvement in all immune system functions that had been impaired by cyclophosphamide. Nevertheless, the observed effect only marked a return to the norm, as most of the analysed parameters were merely restored to their initial levels, with the exception of lysozyme activity, which considerably exceeded the level noted before immunosuppression. This experiment demonstrated that $\beta$-glucan does not directly reverse the changes induced by cyclophosphamide, but it mobilises the remaining functional cells to compensate for the resulting deficiencies. The functions of immunocompetent cells were analysed individually, and further work is needed to investigate the studied polysac- 
charide's effect on the entire immune system. All elements of the immune system are interconnected therefore, every substance that delivers a negative or a positive effect on a given type of cells will, to a varied degree, affect other cells. For this reason, studies that investigate specific immune functions should make a reference to the immune system as a whole.

The results of this study suggest that Biolex-Beta HP ( $\beta-1,3 / 1,6-\mathrm{D}$-glucan) could effectively stimulate the immune system of immunosuppressed subjects, including patients who have undergone cyclophosphamide chemotherapy, subjects exposed to chronic stress, patients with chronic conditions and victims of pesticide poisoning.

\section{Author declares no conflict of interest.}

\section{References}

1. Hoerr FJ (2010): Clinical aspects of immunosuppression in poultry. Avian Dis 54: 2-15.

2. Boraschi D, Penton-Rol G (2013): Perspectives in immunopharmacology: The future of immunosuppression. Immunol Lett doi: 10.1016/j.imlet.2013.11.017.

3. Devaud C, John LB, Westwood JA, et al. (2013): Immune modulation of the tumor microenvironment for enhancing cancer immunotherapy. Oncoimmunology 2: e25961.

4. La Hoz RM, Baddley JW (2013): Infectious complications of immune modulatory agents. Curr Infect Dis Rep 15: 465-471.

5. Sundar KM, Sires M (2013): Sepsis induced immunosuppression: Implications for secondary infections and complications. Indian J Crit Care Med 17: 162-169.

6. Blecha F (2001): Immunomodulators for prevention and treatment of infectious diseases in food-producing animals. Vet Clin North Am Food Anim Pract 17: 621-633.

7. Nelson RP Jr, Ballow M (2003): Immunomodulation and immunotherapy: drugs, cytokines, cytokine receptors, and antibodies. J Allergy Clin Immunol 111 (2 Suppl): 720-743.

8. Foster AP (2004): Immunomodulation and immunodeficiency. Vet Dermatol 15: 115-126.

9. Thacker EL (2010): Immunomodulators, immunostimulants, and immunotherapies in small animal veterinary medicine. Vet Clin North Am Small Anim Pract 40: 473-483.

10. Whitley NT, Day MJ (2011): Immunomodulatory drugs and their application to the management of canine immune-mediated disease. J Small Anim Pract 52: 70-85.

11. Wójcik R, Święcicka-Grabowska G (2006): Influence of KLP602 and Mycobacterium chelonae on specific immunity in turkey vaccinated with ND virus. Med Weter 62: 922-924.

12. Wójcik R, Małaczewska J, Trapkowska S, Siwicki AK (2007): Influence of $\beta-1,3 / 1,6-\mathrm{D}$-glucan on nonspecific cellular defence mechanisms in lambs. Med Weter 63: 84-86.

13. Wójcik R, Milewski S, Małaczewska J, et al. (2008): Defence mechanisms of the offspring of ewes fed a diet supplemented with yeast (Saccharomyces cerevisiae) during pregnancy and lactation. Centr Eur J Immunol 33: 197-201.

14. Skopińska-Różewska E, Siwicki AK, Wójcik R, et al. (2006): Immunostimulatory effect of Immunostim Plus - a standardized fixed combination of Schizandra chinensis with Eleutherococcus senticosus extracts on lymphocyte-dependent cellular immunity in mice. B Vet I Pulawy 50: 461-465.
15. Wójcik R, Siwicki AK, Skopińska-Różewska E, et al. (2009): The in vitro effect of Rhodiola quadrifida and Rhodiola kirilowii extracts on pigs blood lymphocyte response to mitogen Concanavalin A. Centr Eur J Immunol 34: 166-170.

16. Hromadkova Z, Evringerova A, Sasinkova V, et al. (2003): Influence of the drying method on the physical properties and immunomodulatory activity of the particulate (1-3)- $\beta$-D-glucan from Saccharomyces cerevisiae. Carbohydr Polym 51: 9-15.

17. LeibundGut-Landmann S, Gross O, Robinson MJ, et al. (2007): Syk- and CARD9-dependent coupling of innate immunity to the induction of $\mathrm{T}$ helper cells that produce interleukin 17. Nat Immunol 8: 630-638.

18. Taylor PR, Tsoni SV, Willment JA, et al. (2007): Dectin-1 is required for beta-glucan recognition and control of fungal infection. Nat Immunol 8: 31-38.

19. Vetvicka V, Thornton BP, Ross GD (1996): Soluble beta-glucan polysaccharide binding to the lectin site of neutrophil or natural killer cell complement receptor type 3 (CD11b/CD18) generates a primed state of the receptor capable of mediating cytotoxicity of iC3b-opsonized target cells. J Clin Invest 98: 50-61.

20. Xia Y, Vetvicka V, Yan J, et al. (1999): The beta-glucan-binding lectin site of mouse CR3 (CD11b/CD18) and its function in generating a primed state of the receptor that mediates cytotoxic activation in response to iC3b-opsonized target cells. J Immunol 162: 2281-2290.

21. Zimmerman JW, Lindermuth J, Fish PA, et al. (1998): A novel carbohydrate-glycosphingolipid interaction between a beta-(13)-glucan immunomodulator, PGG-glucan, and lactosylceramide of human leukocytes. J Biol Chem 273: 22014-22020.

22. Rice PJ, Kelley JL, Kogan G, et al. (2002): Human monocyte scavenger receptors are pattern recognition receptors for (1->3)-beta-D-glucans. J Leukoc Biol 72: 140-146.

23. Means TK, Mylonakis E, Tampakakis E, et al. (2009): Evolutionarily conserved recognition and innate immunity to fungal pathogens by the scavenger receptors SCARF1 and CD36. J Exp Med 206: 637-653.

24. Ando I, Tsukumo Y, Wakabayashi T, et al. (2002): Safflower polysaccharides activate the transcription factor NF-kappa B via Toll-like receptor 4 and induce cytokine production by macrophages. Int Immunopharmacol 2: 1155-1162.

25. Gantner BN, Simmons RM, Canavera SJ, et al. (2003): Collaborative induction of inflammatory responses by dectin- 1 and Toll-like receptor 2. J Exp Med 197: 1107-1117.

26. Schepetkin IA, Faulkner CL, Nelson-Overton LK, et al. (2005): Macrophage immunomodulatory activity of polysaccharides isolated from Juniperus scopolorum. Int Immunopharmacol 5: 1783-1799.

27. Akremiene D, Kondrotas A, Didziapetriene J, Egidijus K (2007): Effects of $\beta$-glucans on the immune system. Medicina 43: 597-606.

28. Pelizon AC, Kaneno R, Soares AM, et al. (2005): Immunomodulatory activities associated with beta-glucan derived from Saccharomyces cerevisiae. Physiol Res 54: 557-564.

29. Kobayashi M, Fitz L, Ryan M, et al. (1989): Identification and purification of natural killer cell stimulatory factor (NKSF), a cytokine with multiple biologic effects on human lymphocytes. J Exp Med 170: 827-845.

30. Danysza A, Kleinrok Z (1996): Fundamentals of pharmacology for doctors, pharmacists and students of medicine. Volumed, Wroclaw. 
31. Al-Ghazlat S (2009): Immunosuppressive therapy for canine immune-mediated hemolytic anemia. Compend Contin Educ Vet 31: 33-41.

32. Wojcik R, Dabkowska A (2010): The effect of cyclophosphamide on the selected parameters of immunity in rats. Centr Eur J Immunol 35: 1-9.

33. Parry RM, Chandau RC, Shahani RM (1965): A rapid and sensitive assay of muramidase. Proc Soc Exp Biol Med 119: 384-386.

34. Siwicki AK, Anderson DP (1993): Immunostimulation in fish: measuring the effects of stimulants by serological and immunological methods. US Fish Wildl Service-IFI, Olsztyn, 1: 17.

35. Siwicki AK, Studnicka M (1986): Ceruloplasmin activity in carp (Cyprinus carpio). Bamidgeh 38: 126-129.

36. Lowry OH, Rosebrough NJ, Farr AL, Randall R (1951): Protein measurements with the folin phenol reagent. J Biol Chem 193: 265-275.

37. Chung S, Secombes SJ (1988): Analysis of events occuring within teleost macrophages during the respiratory burst. Comp Biochem Physiol 89 B: 539-544.

38. Siwicki AK, Kazun K, Glabski E, et al. (2004): The effect of beta-1,3/1,6-glucan in diets on the effectiveness of anti-Yersinia ruckeri vaccine - an experimental study in rainbow trout $(\mathrm{On}$ corhynchus mykiss). Pol J Food Nutr Sci 54: 59-61.

39. Rook GA, Steele J, Umar J, Dockrel HM (1995): A simple method for the solubilization of reduced NBT and its use as a colorimetric assay for activation of human macrophages by gamma interferon. J Immunol Meth 82: 161-167.

40. Mosmann T (1983): Rapid colorimetric assay for cellular growth and survival: Application to proliferation and cytotoxicity assays. J Immunol Meth 65: 55-63.

41. King PD, Perry M (2001): Hepatoxicity of chemotherapy. Oncologist 6: 162-176.

42. Aubrey DA (1970): Massive hepatic necrosis after cyclophosphamide. Br Med J 3: 588.

43. Snayder LS, Heigh RI, Anderson ML (1993): Cyclophosphamide-induced hepatotoxicity in a patient with Wegener's granulomatosis. Mayo Clin Proc 68: 1203-1204.

44. Čejka J, Bollinger RO, Schuit HRE, et al. (1974): Macroglobulinemia in a child with acute leukemia. Blood 43: 191-199.

45. Zhu LP, Cupps TR, Whalen G, Fauci AS (1987): Selective effects of cyclophosphamide therapy on activation, prolifaration and differentation of human B cells. J Clin Invest 79: 10821090.

46. Abreu LA, Abreu RR (1981): Effect of cyclophosphamide on serum ceruloplasmin oxidase activity in sarcoma bearing rats. Arch Geschwulstforsch 51: 394-397.

47. Małaczewska J, Wójcik R, Jung L, Siwicki AK (2010): The effect of Biolex Beta-HP on the selected parameters of biochemical, specific and non-specific humoral and cellular immunity in rats. Bull Vet Inst Pulawy 54: 75-80.

48. Wójcik R (2010): The effect of brewer's yeast (Saccharomyces cerevisiae) extract on selected parameters of biochemical, humoral and cellular immunity in lambs. Bull Vet Inst Pulawy 54: 181-187.

49. Karin M, Delhase M (2000): The I kappa B kinase (IKK) and NF-kappa B: key elements of proinflammatory signaling. Semin Immunol 12: 85-98.

50. Estrada A, Yun CH, Van Kessel A, et al. (1997): Immunomodulatory activities of oat beta-glucan in vitro and in vivo. Microbiol Immunol 41: 991-998.
51. Suzuki Y, Adachi Y, Ohno N, Yadomae T (2001): Th1/ Th2-balancing immunomodulating activity of gel-forming (1 $\rightarrow$ 3)-beta-glucans from fungi. Biol Pharm Bull 24: 811-819.

52. Estrada A, van Kessel A, Laarveld B (1999): Effect of administration of oat beta-glucan on immune parameters of healthy and immunosuppressed beef steers. Can J Vet Res 63: 261-268.

53. Schepetkin IA, Quinn MT (2006): Botanical polysaccharides: macrophage immunomodulation and therapeutic potential. Int Immunopharmacol 6: 317-333.

54. Guzdek A, Rokita H (1997): Curdlan sulphate modulates protein synthesis and enhances NF- $\mathrm{KB}$ asn C/EBP binding activity in HepG2 cells. Mediators Inflamm 6: 58-63.

55. Zhao R, Ma C, Tan L, et al. (1994): The effect of acupuncture on the function of macrophages in rats of immunodepression. Zhen Ci Yan Jiu 19: 66-68.

56. Yang ZB (1994): Effects of pretreatment with lentinan or krestin on antitumor effector cell activities suppressed by cyclophosphamide. Hokkaido Igaku Zasshi 69: 137-145.

57. Tsuzuki A, Tateishi T, Ohno N, et al. (1999): Increase of hematopoietic responses by triple or single helical conformer of an antitumor (1->3)-beta-D-glucan preparation, Sonifilan, in cyclophosphamide-induced leukopenic mice. Biosci Biotechnol Biochem 63: 104-110.

58. Zhu X-L, Chen A-F, Lin B-Z (2007): Ganoderma lucidum polysaccharides enhance the function of immunological effector cells in immunosuppressed mice. J Ethnopharmacol 111: 219-226.

59. Nudo LP, Catap ES (2011): Immunostimulatory effects of Uncaria perrottetii (A. Rich.) Merr. (Rubiaceae) vinebark aqueous extract in Balb/C mice. J Ethnopharmacol 133: 613-620.

60. Ząbek K, Milewski S, Wójcik R, Siwicki AK (2013): Effect of $\beta-1,3 / 1,6-\mathrm{D}$-glucan in diet on productivity and humoral and cellular defense mechanisms in sheep. Acta Vet Brno 82: 141-146.

61. Paulsen SM, Engastad RE, Robertsen B (2001): Enhanced lysozyme production in Atlantic salmon (Salmo salar L.) macrophages treated with yeast $\beta$-glucan and bacterial lipopolysaccharide. Fish Shellfish Immunol 11: 23-37.

62. Kokoshis PL, Williams DL, Cook JA, Di Luzio NR (1978): Increased resistance to Staphylococcus aureus infection and enhancement in serum lysozyme acitvity by glucan. Science 199: 1340-1342.

63. Orsolic N, Kenzeic AH, Ser L, et al. (2004): Immunomodulatory and antimetastatic action of propolis and related polyphenol compounds. J Ethnopharmacol 94: 307-315.

64. Cleary JA, Kelly GE, Husband AJ (1999): The effect of molecular weight and beta-1,6-linkages on priming of macrophage function in mice by $(1,3)$-beta-D-glucan. Immunol Cell Biol 77: 395-403.

65. Winkelstein A (1973): Mechanism of immunosuppresion: effects of Cyclophosphamide on cellular immunity. Blood 41: 273-284.

66. Gilbert DN, Starr P, Eubanks N (1977): Inhibition of neutropfil chemotaxis by 4-hydroxycyclophosphamide. Cancer Res 37 : 456-459.

67. Cairo MS, Mallet C, Vande Ven C, et al. (1986): Impaired in vitro polymorphonuclear function secondary to the chemotherapeutic effects of vincristine, adriamycin, cyclophosphamide, and actinomycin D. J Clin Oncol 4: 798-804.

68. Szczepanik M, Bryniarski K, Pryjma J, Ptak W (1993): Distinct populations of antigen-presenting macrophages are required for induction of effector and regulatory cells in contact sensitivity response in mice. J Leukoc Biol 53: 320-326. 
69. Marcinkiewicz J, Bryniarski K, Ptak W (1994): Cyclophosphamide uncovers two separate macrophage subpopulations with opposite immunogenic potential and different patterns of monokine production. Cytokine 6: 472-477.

70. Kumari J, Sahoo PK (2005): Effects of cyclophosphamide on the immune system and disease resistance of Asian catfish Clarias batrachus. Fish Shellfish Immunol 19: 307-316.

71. Bryniarski K, Szczepanik M, Ptak M, et al. (2009): Influence of cyclophosphamide and its metabolic products on the activity of peritoneal macrophages in mice. Pharmacol Rep 61: 550-557.

72. Lowry VK, Farnell MB, Ferro PJ, et al. (2005): Purified beta-glucan as an abiotic feed additive up-regulates the innate immune response in immature chickens against Salmonella enterica serovar Enteritidis. Int J Food Microbiol 98: 309-318.

73. Underhill DM, Ozinsky A, Hajjar AM, et al. (1991): The Tolllike receptor 2 is recruited to macrophage phagosomes and discriminates between pathogens. Nature 401: 811-815.

74. Větvicka V, Hanikýrová M, Větvicková J, Ross GD (1999): Regulation of CR3 (CD11b/CD18)-dependent natural killer (NK) cell cytotoxicity by tumour target cell MHC class I molecules. Clin Exp Immunol 115: 229-235.

75. Brown GD, Herre J, Williams DL, et al. (2003): Dectin-1 mediates the biological effects of $\beta$-glucans. J Exp Med 197: 1119-1124.

76. Chen J, Seviour R (2007): Medicinal importance of fungal $\beta-(1 \rightarrow 3),(1 \rightarrow 6)$-glucans. Mycol Res 111: 635-652.

77. Berner ME, Sura BN, Alves Hunter KW Jr (2005): IFN-gamma primes macrophages for enhanced TNF- $\alpha$ expression in response to stimulatory and non-stimulatory amounts of microparticulate $\beta$-glucan. Immunol Lett 98: 115-122.

78. Du E, Kelly I, Mecklenbrauker L, et al. (2006): Selective regulation of IL-10 signaling and function by zymosan. J Immunol 176: 4785-4792.

79. Chan WK, Law HK, Lin ZB, et al. (2007): Response of human dendritic cells to different immunomodulatory polysaccharides derived from mushroom and barley. Int Immunol 19: 891-899.

80. Lackovic V, Borecky L, Sikl D, et al. (1970): Stimulation of interferon production by mannans. Proc Soc Exp Biol Med 134: 874-879.

81. Gately MK, Renzetti LM, Magram J, et al. (1998): The interleukin-12/interleukin-12-receptor system: role in normal and pathologic immune responses. Annu Rev Immunol 16: 495-521.

82. Ranta K, Nieminen K, Saariaho T, et al. (2013): Evaluation of fungal extracts to determine immunomodulatory properties. J Investig Allergol Clin Immunol 23: 226-233.

83. Mosmann TR, Coffman RL (1989): TH1 and TH2 cells: different patterns of lymphokine secretion lead to different functional properties. Annu Rev Immunol 7: 145-173.

84. Vetvicka V, Vetvickova J, Frank J, Yvin JC (2008): Enhancing effects of new biological response modifier $\beta-1,3$ glucan sulfate PS3 on immune reactions. Biomed Pharmacother 62: 283-288.

85. Hamuro J, Rollinghoff M, Wagner H (1980): Induction of cytotoxic peritoneal exudate cells by T-cell immune adjuvants of the $\beta(1 \rightarrow 3)$ glucan-type lentinan and its analogues. Immunology 39: 551-559.

86. Sharma BS (1983): Effects of cyclophosphamide on in vitro human lymphocyte culture and mitogenic stimulation. Transplantation 35: 165-168.

87. Masnaya NV, Ratner GM (2000): Peculiarities of primary humoral immune response in mice with cytostatic disease. Bull Exp Biol Med 129: 370-373.
88. Quakyi EK, Carter PH, Tsai CM, Marti GE (1997): Immunization with meningococcal membrane-bound lipooligosaccharide accelerates granulocyte recovery and enhances lymphocyte proliferation in myelosuppressde mice. Pathobiology 65: 26-38.

89. Bafna AR, Mishra SH (2006): Protective effect of bioactive fraction of Sphaeranthus indicus Linn. against cyclophosphamide induced suppression of humoral immunity in mice. J Ethnopharmacol 104: 426-429.

90. Moynihan J, Cohen N (1989): The kinetics of recovery of leukocyte number and lymphocyte function following an injection of a single high dose of cyclophosphamide in $\mathrm{C} 3 \mathrm{H} / \mathrm{HeJ}$ mice. Int J Immunopharmacol 11: 517-527.

91. Adams JD Jr, Klaidman LK (1993): Acrolein-induced oxygen radical formation. Free Radic Biol Med 2: 187-193.

92. Li LI, Hamilton RF Jr, Holian A (1999): Effect of acrolein on human alveolar macrophage NF- $\kappa$ B activity. Am J Physiol Lung Cell Mol Physiol 277: 550-557.

93. Kehler JP, Biswal SS (2000): The molecular effects of acrolein. Toxicol Sci 57: 6-15.

94. Ben-Efraim S (2001): Immunomodulating anticancer alkylating drugs: targets and mechanisms of activity. Curr Drug Targ 2: 197-212.

95. Robinson JM, Ohira T, Badwey JA (2004): Regulation of the NADPH-oxidase complex of phagocytic leukocytes. Recent insights from structural biology, molecular genetics and microscopy. Histochem Cell Biol 122: 293-304.

96. Bohn J, BeMiller J (1995): (1->3)- $\beta-$ Glucans as biological response modifiers: a review of structure-functional activity relationships. Carbohydrate Polymers 28: 3-14.

97. Rogers NC, Slack EC, Edwards AD, et al. (2005): Syk-dependent cytokine induction by Dectin-1 reveals a novel pattern recognition pathway for $\mathrm{C}$ type lectins. Immunity 22: 507-517.

98. Gross O, Gewies A, Finger K, et al. (2006): Card9 controls a non-TLR signalling pathway for innate anti-fungal immunity. Nature 442: 651-656.

99. Goodridge HS, Simmons RM, Underhill DM (2007): Dectin-1 stimulation by Candida albicans yeast or zymosan triggers NFAT activation in macrophages and dendritic cells. J Immunol 178: 3107-3115.

100. Seo BS, Lee SH, Lee JE, et al. (2013): Dectin-1 stimulation selectively reinforces LPS-driven IgG1 production by mouse B cells. Immune Netw 13: 205-212.

101. Tzianabos AO, Russell PR, Onderdonk AB, et al. (1999): IL-2 mediates protection against abscess formation in an experimental model of sepsis. J Immunol 163: 893-897.

102. Dong SF, Chen JM, Zhang W, et al. (2007): Specific immune response to HBsAg is enhanced by beta-glucan oligosaccharide containing an alpha-(1->3)-linked bond and biased towards M2/Th2. Int Immunopharmacol 7: 725-733.

103. Brown GD (2006): Dectin-1: a signaling non-TLR pattern-recognition receptor. Nat Rev Immunol 6: 33-44.

104. Zhao Ch, Li M, Luo Y, Wu W (2006): Isolation and structural characterization of an immunostimulating polysaccharide from fuzi, Aconitum carmichaeli. Carbohydr Res 341: 485-491.

105. Wang G, Lin W, Zhao R, Lin N (2008): Effects of six polysaccharides extracted from plants on the immunological cells of mice. Wei Sheng Yan Jiu 37: 577-580.

106. Bi H, Gao T, Liu D, et al. (2013): Structures of ( $1 \rightarrow 6)-\beta$-D-glucans from Bulgaria inquinans (Fries) and their immunological activities. Carbohydr Polym 93: 547-552. 